Peer-reviewed scientific periodical, focusing on legal and economic issues of antitrust and regulation.

\title{
What Role for EU Competition Law in Regulated Industries? Reflections on the Judgment of the General Court of 17 December 2015 Orange Polska v European Commission (Case T-486/11)
}

by

\section{Sandra Marco Colino*}

\section{CONTENTS}

I. Introduction

II. Background: the behaviour of Orange Polska and the decision of the Commission

III. The Judgement of the General Court

1. Duty to motivate findings of past infringements

2. Adequacy of the fine: where is the effects-based approach?

3. Mitigating factors and the prior intervention of NRAs

IV. The significance of the GC's Orange Polska ruling: an assessment

V. Conclusion

Key words: antitrust; competition law; sector-specific regulation; network industries; refusal to supply; essential facilities.

JEL: K20; K21; K22; K23

* Assistant Professor, Faculty of Law, Chinese University of Hong Kong. Director, Centre for Financial Regulation and Economic Development (CFRED). Deputy Director, European Union Academic Programme in Hong Kong (EUAP). Non-Governmental Advisor to the International Competition Network. E-mail: s.marcocolino@cuhk.edu.hk

The work described in this paper was substantially supported by a grant from the Research Grants Council of the Hong Kong Special Administrative Region, China (Project No. CUHK 401612).

Article received: 2 September 2016; accepted: 9 October 2016.

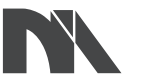

\section{Ministry of Science and Higher Education}

Republic of Poland
The creation of the English-language version of these publications is financed in the framework of contract No. 768/P-DUN/2016 by the Ministry of Science and Higher Education committed to activities aimed at the promotion of education. 


\section{Introduction}

On $17^{\text {th }}$ December 2015, the General Court of the European Union (GC) confirmed a fine of over EUR 127 million imposed by the European Commission (hereinafter the Commission) on the Polish telecommunications company Orange Polska (hereinafter OP), formerly known as Telekomunikacja Polska ${ }^{1}$. According to the fining decision, issued in 2011 (hereinafter the Commission decision), OP abused its dominant position by refusing access to its wholesale broadband services to new entrants, acting in contravention of Article 102 of the Treaty on the Functioning of the European Union (TFEU) $)^{2}$.

Abuse of dominance is a particularly convoluted area of competition law. The long-awaited judgments of the GC in Intel $^{3}$ and of the Court of Justice in Post Danmark $\mathrm{II}^{4}$, handed down shortly before the Orange Polska ruling, have absorbed the attention of antitrust experts, and the ongoing Google investigation is the cause célèbre of the moment. In such an unsettled context, the case against the Polish incumbent has gone somewhat by the wayside. Yet the GC's endorsement of the Commission decision is not without significant implications for the treatment of constructive refusals to supply in network industries. By confirming the imposition of one of the most substantial financial penalties ever levied on a broadband Internet service provider, the European courts have once again given their blessing to the Commission's activism in the liberalization of telecommunications markets (de Streel, 2014). Interestingly, by the time OP was punished, the infringement had allegedly come to an end following the intervention of the national regulatory authority (hereinafter NRA). The decision thus fanned the flames of the debate, particularly fervent among Polish scholars, as to whether competition law should intervene where there is sector-specific regulation.

The argument that the action of the relevant NRAs should be prioritised over the application of competition law by the national competition authorities (NCAs) and the Commission in regulated industries (Stawicki, 2011) finds support in the prevailing view in the United States (US) that treats regulation and antitrust as antonyms (Maggiolino, 2015; Díez, 2015) ${ }^{5}$. Such a position has been somewhat fuelled by the relatively inconsistent case law of the Polish Supreme Court, which has appeared to suggest that incumbent operators

\footnotetext{
1 Case T-486/11 Orange Polska S.A. v European Commission 17 December 2015 (nyr), hereinafter GC ruling.

2 Commission decision of 22 June 2011, COMP/39.325 - Telekomunikacja Polska.

3 Case T-286/09 Intel v Commission, EU:T:2014:472.

${ }^{4}$ Case C-23/14 Post Danmark A/S v Konkurrencerådet, EU:C:2015:651.

5 Case Verizon Communications, Inc. v. Law Offices of Curtis V. Trinko 540 U.S. 398 (2004).
} 
should be immune to competition law when they act on the instructions of the regulator ${ }^{6}$. However, the predominant view is that competition law and regulation can, and should, coexist. EU competition law can step in when NRAs fall short in their attempts to ensure effective liberalization, as the landmark Deutsche Telekom case confirmed ${ }^{7}$.

The investigation of OP's behaviour is as interesting as it is complex. Since 2005, there have been decisions of the NRA, the NCA, the Court of Justice (which had to decide on the adequacy of the action taken by the Polish NCA), the Commission, and most recently the GC. This paper discusses the implications of the GC's judgment for the application of EU competition law to regulated network industries, and the power of the Commission to take action in such cases. It first explores the background against which the ruling was made, including the Commission decision (part II), to subsequently delve into the GC judgement (part III) and conduct an assessment of the significance of the case (part IV). Finally, conclusions are drawn.

\section{Background: the behaviour of Orange Polska and the decision of the Commission}

Between 2005 and 2009, OP provided wholesale broadband internet access services by means of unbundled access to the local loop in Poland (although the decision of the Commission is addressed to Telekomunikacja Polska, the company's former name, throughout this paper the company will be referred to as OP, for the sake of consistency). Unbundled access to the local loop allows new entrants, or Alternative Operators (AOs), to use the infrastructure of the incumbent to offer services in competition with the former monopolist. In this period, two wholesale broadband access products existed in the Polish market: unbundled access to the local loop itself (Local Loop Unbundling, LLU) and broadband access (Bitstream Access, BSA). OP was the only provider of such wholesale broadband products in the entire country, which also held a dominant position in the downstream retail market of broadband access services offered by operators to end users. To operate in the latter, OP's competitors required access to the incumbent's wholesale products. Both EU and national sectoral regulation impose an obligation on operators

\footnotetext{
6 Judgment of Supreme Court of 17 March 2010, case III SK 40/09.

7 Commission decision COMP/C-1/37.451, 37.578, 37.579 - Deutsche Telekom (2003) and case T-271/03 Deutsche Telekom AG v Commission, ECLI:EU:T:2008:101.
} 
with "significant market power" to grant AOs access to LLU, and to publish a Reference Offer ${ }^{8}$.

The Commission initiated proceedings against OP on $17^{\text {th }}$ April 2009, following an inspection of the company's premises in 2008. The Commission alleged that the incumbent had not ensured appropriate access to its network through, inter alia, the following practices: unreasonable conditions for accessing its wholesale broadband products; a tendency to fail to meet the regulatory deadline of 90 days for concluding negotiations; network access restrictions through unreasonable rejections and difficult technical conditions for connecting; the limitation of subscriber lines, and unreasonable rejection of new entrants' orders to activate them; and the failure to provide reliable general information indispensable for $\mathrm{AOs}^{9}$. These practices not only contravened sector-specific regulation, but also violated Article 102 TFEU insofar as they amounted to a refusal to supply which precluded AOs from competing in downstream markets.

OP questioned the Commission's competence to act on multiple grounds. One of the principal arguments put forward in this respect related to the fact that both the NRA and the Polish competition authority had already taken action. Indeed, since 2005, the Polish NRA, Urzad Komunikacji Elektronicznej (hereinafter UKE) had attempted to force OP to comply with its regulatory obligations, with limited success. In a string of decisions, it fined the company for not fulfilling its obligations to grant access to the network, and imposed commitments (Kowalik-Bańczyk, 2015, p. 194). It was only under the threat of functional separation that the NRA managed to twist OP's arm into signing a voluntary agreement in October 2009, in which the incumbent vowed to take measures to ensure genuine market access for AOs. Since the agreement failed to solve all the problems, the UKE issued further decisions in December 2010 and April 2011 to respectively encourage LLU and BSA access ${ }^{10}$. OP thus alleged that "ex post intervention by the Commission on the issues for which UKE has already exercised and continues to exercise effective control does not seem appropriate" 11 . The Commission rejected this claim, reminding OP that the case law of the European courts had consistently defended that "competition rules may apply where sector specific

8 Regulation (EC) No. 2887/2000 of the European Parliament and of the Council of 18 December 2000 on Unbundled Access to the Local Loop (OJ L 336, 30.12.2000, p. 4), repealed and carried over in Directive 2002/19/EC of the European Parliament and of the Council of 7 March 2002 on Access to, and Interconnection of, Electronic Communications Networks and Services (OJ L108, 24.04.2002, p. 7), amended by Directive 2009/140.

9 Commission decision, paras 81-118.

${ }^{10}$ Commission decision, paras 78-79.

11 TP's presentation at the Oral Hearing, p. 4. 
legislation exists"12. In this case, UKE had not assessed the compatibility of OP's behaviour with Article 102 TFEU, so the issue was fairly straightforward. However, the company was reminded that, as recognised in Deutsche Telekom and Masterfoods, even if it had done so "the Commission cannot be bound by a decision taken by a national body pursuant to Article 102 TFEU"13. In any case, the Commission found that the ne bis in idem principle was not breached by its intervention since there was no unity of the legal interest protected ${ }^{14}$. Sectoral and competition law serve different purposes.

With regard to the action of the Polish competition authority, Urzad Ochrony Konkurencji i Konsumentów (UOKiK), the Commission held that its investigation had not focused on the application of Article 9 of the Polish competition law, the national equivalent of Article 102 TFEU $^{15}$. Importantly, the UOKiK's non-infringement decision was challenged before the Court of Justice by Netia SA (known at the time as Tele2 Polska), a competitor of OP. In its controversial judgement, the Court stated that Article 5 of Regulation 1/2003 should be interpreted to mean that only the Commission is empowered to make negative decisions, that is, to formally declare that no breach of EU competition law had occurred ${ }^{16}$. According to the Court, such a view aims to ensure the uniform application of Articles 101 and 102 TFEU. Unsurprisingly, the ruling has been subject to harsh doctrinal criticism. Petit, for instance, has said that it is premised on, inter alia, a "flawed understanding of the concept of effectiveness of EU competition law, dubious literal reading of Article 5, inconsistency with VEBIC, long-term legal uncertainty effects" (Petit, 2011).

As a consequence of the above reasoning, the Commission found that OP's practices at best delayed, and at worst altogether prevented, the surge of competition in broadband markets by using its monopoly over wholesale markets to protect its dominant position in the downstream retail markets. On the basis of the Guidelines on the Method of Setting Fines Imposed Pursuant to Article 23(2)(a) of Regulation No. $1 / 2003^{17}$, the Commission imposed a fine amounting to ten percent of the average value of sales on the relevant markets, and multiplied it by the duration of the unlawful behaviour. It then deducted the quantities already paid by the incumbent by virtue of the fines imposed by UKE. The final amount reached was EUR 12755419418 .

12 Commission decision, para. 126.

13 Commission decision, para. 128.

14 Commission decision, para. 137.

15 Act of 16 February 2007 on the protection of competition and consumers (Ustawa o ochronie konkurencji i konsumentów), Dz.U. 2007, No 50, pos. 331.

16 Case C-375/09, Prezes Urzędu Ochrony Konkurencji i Konsumentów v Tele2 Polska sp. z o.o. ECLI:EU:C:2011:270, para. 29, and Commission decision, para. 129.

17 OJ C 210, 01.09.2006, p. 2.

18 Commission decision, paras 917-921. 


\section{The Judgement of the General Court}

When the case was brought before the GC, OP did not put into question the existence of abusive practices. Instead, its appeal was founded on multiple technical aspects of the Commission decision, including: the failure to prove a legitimate interest in the pursuit of a past infringement; alleged breaches of procedural guarantees required by the European Convention of Human Rights (ECHR); and the method of calculating the fine. The sheer volume of issues raised is testimony to the kind of impressive lawyering one has grown accustomed to in abuse cases, since the powerful companies under investigation usually have the means to fight until they have exhausted every defence channel. Given the impossibility to deal with every petition in this brief paper, the issues raised by the most solid grounds for appeal have been cherry-picked for discussion.

\section{Duty to motivate findings of past infringements}

The single plea put forward for full annulment was the fact that the infringement had allegedly ended nearly two years before the adoption of the contested decision. According to Article 7(1) of Regulation 1/2003, to pursue a past infringement the Commission would need to demonstrate a legitimate interest. The Court took this opportunity to insist on the difference between declaratory findings of past infringements and sanctions. A declaratory finding is the mere establishment of a breach (Frese, 2014, p. 162-164). The Commission adopts declaratory findings, inter alia, when there is a risk that the anticompetitive practice will be resumed ${ }^{19}$ and for facilitating damage claims ${ }^{20}$. While such findings may be accompanied by sanctions, they are not sanctions in themselves. The Commission is under an obligation to motivate declaratory findings relating to past contraventions, but its power to punish is not time-barred and does not need to be justified ${ }^{21}$. As a consequence, the GC confirmed that there is no duty to prove a legitimate interest when penalties accompany the declaration of an infringement (Salerno, 2016). Read in conjunction with previous jurisprudence, the ruling heightens the broad leeway granted to the Commission to tackle past infringements: sanctions can, in principle, always be imposed, and declaratory findings are only put

\footnotetext{
19 Case 7/82 GVL, ECLI:EU:C:1983:52, para. 27.

20 Joined cases T-22/02 and T-23/02 Sumitomo, ECLI:EU:T:2005:349, paras 137-138.

21 GC ruling, paras 69-80.
} 
into question when they are excessively delayed ${ }^{22}$. It is hoped that in future cases the European courts will provide further clarifications as to whether the Commission's fining powers are indeed limitless in time.

\section{Adequacy of the fine: where is the effects-based approach?}

OP raised multiple challenges with regard to the amount of the fine imposed, all of which were quashed by the GC. Importantly, the court had to confront its repeated reluctance to adopt an effects-based approach for the analysis of abusive practices, which appears to be at odds with the Commission's (nonbinding) suggestion that it would focus on consumer harm when pursuing exclusionary abuses ${ }^{23}$. Effects were relegated to virtual irrelevance with the GC's confirmation that the Commission did not need to consider the duration and intensity of each individual practice to adjust the fine ${ }^{24}$. Moreover, the court confirmed its view that actual effects are not necessary to prove an infringement. In this case, it argued, the fine was imposed as a consequence of the nature of the infringement, its geographical scope, the company's market share and its implementation of the infringement ${ }^{25}$. This position is hardly surprising following the outcome of previous cases such as Intel, which show that specific consumer harm is not analysed when finding the existence of an abuse (Nihoul, 2014). While controversial, the message sent to incumbents about the legal consequences they may face if they prevent market access is loud and clear.

The proportionality of the substantial fine was also put into question. The $\mathrm{GC}$ defended the fairness of the amount given the seriousness of the breach. Once again, the categorization of the violation as serious did not require an effects analysis. According to the court, the gravity resided in the fact that the company abused its power as former legal monopoly to engage in "multiple, flagrant, persistent and intentional breaches", being fully aware of the illegality of its conduct, which affected product markets "of considerable size and social importance" 26 .

22 Sumitomo, supra note 21.

23 Guidance on the Commission's Enforcement Priorities in Applying Article [102] of the EC Treaty to Abusive Exclusionary Conduct by Dominant Undertakings (OJ C 45, 24.02.2009, p. 7), hereinafter Guidance Paper.

24 GC ruling, paras $117-57$.

25 GC ruling, paras $158-175$.

${ }^{26}$ GC ruling, paras 178-181. 


\section{Mitigating factors and the prior intervention of NRAs}

The relationship between sectorial regulation and competition law came up in the examination of the mitigating factors that, according to OP, the Commission overlooked when deciding the final amount of the fine. OP alleged that it had made considerable investments since entering into the agreement with UKE in order to modernise the national fixed-line infrastructure for both AOs and end users, yet those investments had not been taken into consideration to adjust the penalty. The court avoided going into a thorough analysis of the interaction of regulation and competition (Tóth, 2016). It argued that only investments that amount to compensatory measures for third parties, such as the ones in the Nintendo case, can be taken into consideration ${ }^{27}$. The investments made by OP may have reaped some benefits to those affected by the illegal conduct, but they were not compensatory measures strictly speaking. The sole intention behind OP's investments was to avoid the functional separation threatened by $\mathrm{UKE}^{28}$. In any event, the Commission had benevolently chosen the date of the signature of the agreement as the date that marked the end of the infringement ${ }^{29}$.

Other mitigating factors put forward by OP were its voluntary cessation of the illegal conduct and the commitments it made. With regard to the voluntary termination of the infringements, the GC highlighted that there had to be a causal link between the interventions of the Commission and the termination of the infringement concerned ${ }^{30}$. In this case, there was gradual compliance, motivated by a desire to avoid the penalties of the NRA rather than by the Commission's intervention. The causal link could thus not be established ${ }^{31}$. As for the commitments, the court established that the undertaking had to cooperate beyond its legal obligation to do $\mathrm{so}^{32}$. The Court found that in this case the commitments adopted did not intend to facilitate the establishment of the infringement but merely to terminate $i^{33}$. Such behaviour did not amount to special cooperation.

\footnotetext{
27 GC ruling, paras 197-201.

28 GC ruling, para. 197.

29 GC ruling, para. 207.

30 GC ruling, paras 214-215.

31 GC ruling, para. 213.

32 GC ruling, para. 219.

33 GC ruling, para. 223.
} 


\section{The significance of the GC's Orange Polska ruling: an assessment}

The Commission's intervention against the Polish broadband incumbent once again demonstrates the institution's hands-on approach when it comes to the liberalization of regulated network industries. It does not hesitate to intercede where the actions of NRAs prove insufficient to erase the resilient vestiges of former legal monopolies. Of the tools it has at its disposal - the ex ante review of NRAs' decisions using Articles 7 and $7 \mathrm{a}$ of the Electronic Communications Framework Directive ${ }^{34}$, going after Member States' for their failure to comply with EU law on the basis of Article 258 TFEU, and the use of EU competition law provisions - it relies principally on EU antitrust, the faster and less politicised means of intervention (de Streel, 2014, p. 205). The European courts, on their part, have ensured that the Commission has wide discretion to act not only where NRAs have previously acted but also, as this investigation and the related Tele 2 Polska case prove, where NCAs seemingly do not apply Articles 101 and 102 TFEU in a way that ensures the effectiveness of EU competition law.

Is intervention through competition law necessary, or even acceptable, in heavily regulated sectors? The question is latent in OP's allegations during the investigation and appeal process. In this regard, de Streel has raised technical concerns about institutional (in)equilibrium when the Commission effectively behaves as a European telecoms regulator (de Streel, 2014, p. 206-207). At the same time, Postrel sees no need for antitrust in markets subject to constant transformation by innovation (Postrel, 1999). While the latter observation may ultimately hold true, it does not address the immediate risks inherent to the presence of incumbents in network industries, and their ability to exploit their positions to leverage their dominance ${ }^{35}$. Ibáñez Colomo rightly points out that the concurrent use of competition and regulation is acceptable insofar as the two promote similar, but not identical, objectives. While regulation creates or stimulates competition in markets in which it would otherwise not spring spontaneously, antitrust protects the resulting (artificially cultivated) competition (Ibáñez Colomo, 2016, p. 3). Safeguarding competition in these markets is as paramount as in others, and sectoral regulation is not the panacea of all ills affecting network industries. Moreover, the principle of primacy of EU law would justify the precedence of Articles 101 and 102 TFEU in cases where national (sector-specific) regulation does not sufficiently or adequately protect

34 Directive 2002/21/EC of the European Parliament and of the Council of 7 March 2002 on a common regulatory framework for electronic communications networks and services (OJ L108, 24.04.2002 p. 33), hereinafter the Framework Directive.

35 US v Microsoft Corp., 253 F.3d 34 (D.C. Cir. 2001). 
the interests of the Union. From this standpoint, the discretion afforded to the Commission by the European Courts to act in regulated industries would be justified where the action of NRAs is insufficient to correct the behaviour of incumbents (de Streel, 2014, p. 208).

While ruling out the application of competition law altogether is unadvisable, the - more complex - question raised by the Orange Polska case is how antitrust should apply to recently liberalised industries. There is little doubt that the Commission and the European courts adapt substantive standards to investigations affecting regulated sectors. Such adjustments are inherent to the versatile nature of competition law, and its inextricable link to the specific context in which it applies. In fact, the very modus operandi of Article 102 TFEU entails imposing different standards, and placing special responsibility, on companies in possession of market power. Liberalised network industries display a specific problem relating to the incumbents' continued control of an upstream market which AOs must access in order to compete in downstream markets, and which can be used as a bottleneck for effective competition in the latter. While monopoly power may be tackled with sectorial regulation, holding such control is not anticompetitive in itself. Competition law is only concerned with the use of that power with a view to eliminating competition in downstream markets. Constructive refusals to supply in network industries, such as the ones effected by OP, could well have that effect.

A consequence of this adaptability of EU competition law is that effectiveness is prioritised over consistency in its application. The GC repeatedly refers to the effectiveness of Article 102 TFEU when refuting OP's pleas. At the same time, the Commission has explicitly referred to different standards to assess refusals to supply in industries liberalized through regulation as part of its policy ${ }^{36}$. The focus on the effet utile and the importance given to context is valuable in many respects. In dynamic markets, bright lines risk becoming mere slogans if one does not take into account the specific facts that led to the adoption of basic principles (Coates, 2016). However, the European courts need to ensure that some consistency is attained. Otherwise, as noted by de Streel, there is a significant risk of developing sector-specific competition law, leading to the contamination of bright lines with sectorial reasoning (de Streel, 2014). In this regard, the GC ruling against OP does not really help to reconcile effectiveness and consistency.

36 Guidance Paper, para. 82. 


\section{Conclusion}

The OP saga is not over yet, as the company has lodged an appeal against the judgement of the GC before the Court of Justice ${ }^{37}$. Tóth has noted that the GC ruling reflects a firepower of EU competition law "much greater than [that of] national sector-specific regulation, which can be useful if the powers of regulatory authorities lack effectiveness" (Tóth, 2016). The case is a vivid illustration of the complexity of the concurrent intervention of NRAs applying national sectorial regulation, NCAs applying national and EU competition law, and the Commission applying EU competition law in liberalised markets. As a result of the multiplication of legal proceedings, there will necessarily be increased transaction costs and decreased legal certainty (de Streel, 2014). These issues are virtually inescapable in network industries, where the behaviour of the incumbent has repercussions for both regulation and competition law, and neither discipline alone can always fix all the harm caused by the actions of the former monopolist.

The application of competition law in situations where regulators have already intervened is not only conceivable, but may also be valuable: antitrust can help protect competition in contexts in which it has been artificially invigorated through regulation, and where the presence of incumbents with market power could hamper effective liberalisation. This view serves to justify the alleged activism of the Commission in regulated markets through Article 102 TFEU, and appears to be guiding the decision-making process of the European courts. Following the GC ruling, it is clear that the Commission has very broad powers to pursue and punish constructive refusals to supply, even if they took place in the past and the relevant NRA has already intervened to try to correct the behaviour of the incumbent. Moreover, where the NCA has also taken action, the Commission's interference is also plausible, provided that the illegal conduct has not been adequately tackled by the national authority. In this regard, the ruling leaves two important questions unanswered. The first is whether there really is no time limit whatsoever for the issuance of fining decisions. They can seemingly be imposed retroactively and with no duty to motivate legitimate interest on the part of the Commission. The second is how to ensure the effective, decentralised application of EU competition law where, as the related Tele 2 Polska case clarified, NCAs are precluded from making negative decisions on the application of Article 102 TFEU. While the judgement of the GC gives broad powers to act to ensure effectiveness, greater certainty might be desirable.

37 Case C-123/16 P Orange Polska v Commission, nyd. 


\section{Literature}

Bernatt, M. (2012). Convergence of Procedural Standards in the European Competition Proceedings. Competition Law Review, 8(3), 255-283.

Coates, K. (2016). An Emerging Competition Law for a New Economy? Introductory Remarks for the Chillin Competition Panel. 21 $1^{\text {st }}$ Century Competition: Reflections on Modern Antitrust January 21. Retrieved from: http://www.twentyfirstcenturycompetition. com/2016/01/an-emerging-competition-law-for-a-new-economy-introductory-remarksfor-the-chillin-competition-panel/ (02.09.2016).

Díez, F. (2015). Promoting Competition in Digital Markets: a Case Against the Google Case, and the Futile Search of 'Neutrality' in On-line Searches. SSRN. Retrieved from: http://ssrn.com/abstract=2691058 (02.09.2016).

Frese, M.J. (2014). Sanctions in EU Competition Law: Principles and Practice. Oxford: Hart Publishing.

Ibáñez Colomo, P. (2016). EU Competition Law in the Regulated Network Industries. In: ed. J. Galloway (ed.). Intersections of Antitrust: Policy and Regulation. Oxford: Oxford University Press.

Kowalik-Bańczyk, K. (2015). Regulatory Approach to Competition Law in the Practice of the Polish Competition Authority - A Critical Assessment. In: J. Drexl and F. di Porto (eds), Competition Law as Regulation (pp. 174-206). Cheltenham: Edward Elgar.

Kuik, K. and Mościbroda, A. (2012). 2010 and 2011 EU Competition Law and SectorSpecific Regulatory Jurisprudence and Case Law Developments with a Nexus to Poland. Yearbook of Antitrust and Regulatory Studies 5(2), 157-190.

Maggiolino, M. (2015). The Regulatory Breakthrough of Competition Law: Definitions and Worries. In: J. Drexl and F. di Porto (eds), Competition Law as Regulation (pp. 3-26). Cheltenham: Edward Elgar.

Marco Colino, S. (2011). Competition Law of the EU and UK, $7^{\text {th }}$ edn. Oxford: Oxford University Press.

Moir, G. (2015). Orange Polska v Commission (Case T-486/11). Shepherd \& Wedderburn December 17. Retrieved from: http://www.shepwedd.co.uk/knowledge/orange-polskav-commission-case-t-48611 (02.09.2016).

Nuechterlein, J.E. and Weiser, P.J. (2013). Digital Crossroads: Telecommunications Law and Policy in the Internet Age, $2^{\text {nd }}$ edn. Cambridge: MIT Press.

Nihoul, P. (2014). The Ruling of the General Court in Intel: Towards the End of an Effect-based Approach in European Competition Law? Journal of Competition Law and Economics 5(8), 521-522.

Petit, N. (2011). The Perverse Effects of the Court's Ruling in Tele2 Polska. Chillin' Competition June 17. Retrieved from: https://chillingcompetition.com/2011/06/17/theperverse-effects-of-the-courts-ruling-in-tele2-polska/ (02.09.2016).

Postrel, V. (1999). What Really Scares Microsoft. New York Times Nov 8. http://www. nytimes.com/1999/11/08/opinion/what-really-scares-microsoft.html? pagewanted = all (02.09.2016).

Salerno, F.M. (2016). Orange Polska: No Duty to Motivate the Commission's Legitimate Interest in Finding a Past Infringement. Journal of Competition Law \& Practice (forthcoming). 
Stawicki, A. (2011). The Autonomy of Sector-Specific Regulation - Is it Worth Protecting? Further Thoughts on the Parallel Application of Competition Law and Regulatory Instruments. Yearbook of Antitrust and Regulatory Studies 4(4), 115-133.

de Streel, A. (2014). The Antitrust Activism of the European Commission in the Telecommunications Sector. In: P. Lowe and M. Marquis (eds), European Competition Law Annual 2012: Competition, Regulation and Public Policies (pp. 189-208). Oxford: Hart Publishing.

Tóth, A. (2016). General Court Judgement on Orange Polska - Fine for Abusive Conduct. European Networks Law and Regulation Quarterly (forthcoming). 